\title{
The Art of Tembang Macapat: Exclusiveness of the Forms, Value Aspects, and Learning Approach
}

\author{
Udjang Pairin M. Basir \\ Universitas Negeri Surabaya \\ Surabaya, Indonesia \\ udjangjw@unesa.ac.id
}

\author{
Sayid Marifatulloh \\ Universitas Hasyim Asy'ari \\ Jombang, Indonesia
}

\begin{abstract}
Tembang macapat" is a part of Javanese traditional artwork with special characteristics. From the verbal aspect, Tembang macapat is classified in the category of bound poetry (not free poetry). It contains guru lagu, guru wilangan, and guru gatra which bounds respectively during the process of making each lines and the technique to sing it. As a part of soul expression, this type of Tembang contains exotic and exclusive values. In addition to its distinctive form aspect, "Tembang macapat" also contains certain messages related to the value of philosophic and didactic on each type of Tembang. Nevertheless, from the pragmatic aspect and its application in today's society, the prospect is less encouraging. This is due to the weakness of coaching and preservation in the community especially the cultural connections to the younger generation. The phenomenon of the shifting direction of global culture must be a consideration of the direction of the development of "Tembang macapat" both in the format and the content so that the connectivity becomes part of mind portrait in the more practical, accommodative, expressive, and functional era.
\end{abstract}

Keywords - tembang macapat; exclusiveness; value; approach; learning.

\section{INTRODUCTION}

In the curriculum of traditional language (Javanese), the art of Tembang is a part of prioritized learning materials. As part of local curriculum, the material of Tembang is included in the discussion of language learning themes (listening and reading) of literature scope, especially Tembang macapat subtheme [1], [2]. The purpose leads to introducing, learning, preserving, and developing traditional culture with positive and noble values.

The art of Tembang is taught to the students as an attempt of connecting culture. By innovative and creative way of teaching Tembang art, it is expected that teachers can transform various aspects of positive ancestral tradition to their students [3], [4]. Many aspects of the values contained in the art of Tembang can be used as an alternative in teaching mental and moral to students. By implementing appropriate teaching of Tembang art and adapted to the situation and the children development phases, it is expected to grow a sense of loving culture. The impact will reinforce the value of learners (Javanese) appreciation and love on the work of national culture [5], [6], [7].

Unfortunately, reality is very far from what is expected. The common causes come from internal and external factors.
Internal issues are related to the existence of Tembang art that the structure and the way of understanding are relatively difficult. While the external factors concern on the aspect of teachers' low ability, inadequate time allocation, and the character of too exclusive Tembang lyric is considered less appropriate to the recent era.

Faced with such a situation, teachers as the spearhead in the preservation, development and fostering of Tembang art can actually play their role more and more. The teachers' main provision is trying to understand the characteristics of Tembang art (macapat), adapting values functionally, and having a willingness and skill to compose the content and language model (lyric) contextually. This is important in order to overcome obstacles that hamper students' understanding. After that, think about how to make preparations to present and determine the teaching strategies in schools that can generate students' motivation.

\section{A. Tembang Literature}

In accordance with the material orientation drawn from the source of the Local Content Curriculum, subject of traditional language (Javanese), then this discussion focuses on macapat Tembang. It is because the type of Tembang contains many values that should be learned, introduces and known by the students to build their character that is experiencing critical cultural paradigm. Tembang macapat in Javanese culture is intended as a form of poetry which is bound to guru lagu", guru wilangan, guru gatra [8], [9]. Guru lagu is the fall of vowel sounds (dhong-dhing) at the end of the Tembang line. Guru wilangan is the number of syllable in each type of Tembang, while guru gatra is the rule of line number in each type of Tembang [4].

\section{B. Tembang and the Challenge}

Tembang as a part of the form of artistic expression has long been known in Javanese culture. In terms of shape, structure, and content, it can be regarded as a peculiar, unique, complex and didactic artwork model. The peculiarity, uniqueness and complexity of the Tembang as an artwork in Javanese culture is apparent with the existence of very strict various rules related to the system of composing stanza, rhyme and terms of the number of syllables on each type of Tembang. Similarly, in terms of content meaning, each type of Tembang has a different philosophical symbolic features. The art of Tembang as a product of past culture, has undergone the 
peak of its glory in the era of Mataram and Surakarta kingdom. Lots of great works written in the language of Tembang include: Bratayuda, Serat Panitisastra, Serat Arjuna Sasra, Serat Menak, Serat Tajus Salatin, Babad Giyanti as the work of a poet Yasadipura; Serat Wulangsunu by Pakubuwana IV; Serat Centhini and Serat Wulangreh by Pakubuwana V; Serat Paramayoga, Serat Pustakaraja, and Serat Cemporet, etc by Raden Ngabehi Ranggawarsito [10].

Yet it is admitted that the work of Tembang that is considered to have a high cultural values, is currently quite difficult to obtain and the development is constrained. Indeed, some of Javanese people still use it, but it is only used in limited community, such as jagong bayen activities (prayer event at a newborn babies) in the countryside; Setu Legen event (held on Saturday Legi) in Lamongan, etc. However, related to the activities of copying, adapting or introducing the contents more widely as preservation and development efforts is still stagnant. Therefore, it can be understood that for most people (Javanese) nowadays, including the process of teaching in schools, the art of Tembang is viewed more as something difficult and complicated. The obstacle is not only the scarcity of the source book as guidance of teaching art of Tembang, but also the massive penetration of global culture that is instant, attractive and not long-winded.

Such characters are not possessed by Tembang literature and at the same time become one of the obstacles in teaching at schools that needs a different solution. In terms of guidebooks of Tembang, it is still available but very rare. Some books are written in Javanese and some are written in Latin letters. Those books such as: (1) Serat uran macapat, kangge sinau nyekar tuwin nyekaraken tumrap student ing pamulangan Jawi, written by Hardjosoewito in 1930. (2) Serat heritage, kangge mulangaken ing grija tuwin ing pamatulangan mawi titiswara, written by $\mathrm{Ki}$ Hadjar Dewantara in 1930. (3) Nyinau sekar macapat, titi laras lan solmisasi, written by Dwidjo Widjaja in 1976. (4) Sekar macapat kangge cepengan para guru Sekolah Dasar, written by Arintaka in 1981. And (5) Limpad nembang macapat, written by Padmosoekotjo in 1957.

\section{Values in Tembang}

As typically traditional literature in Javanese culture, Tembang literature was created as expression embodiment of the author's thoughts associated with the situation and conditions of society. Various matters are implied in Tembang literary such as: entertainment, advice, education, social relationships, expressions of sadness and joy, criticism, honesty and loyalty, divinity, etc. From the various aspects of the content, it may be utilized as alternative way of fostering youth character adjusted to the context. Thus, the discussion covers (1) type of Tembang, and (2) content of Tembang.

\section{a) Types of Tembang}

From cultural context, the distinctive Javanese Tembang is divided into 3 types; (1) Tembang gedhe (TG), (2) Tembang tengahan (TT), and (3) Tembang alit, also called Tembang macapat (TM). All those three are different in terms of the era, as well as the mission and characteristics. Tembang
Gedhe is also called sekar ageng. As a prototype of traditional poetry, Tembang Gedhe has certain rules, for example: stanza of Tembang gedhe may consist of 4, 5, 6 rows or gatra, etc. Tembang Gedhe consists of 4 types; (1) salisir, is the type of TG which each stanza consists of 5 to 10 syllables; (2) siliran, is TG which each stanza consists of 11 to 20 syllables; (3) raketan, is TG which each stanza consists of 21 to 30 syllables and (4) simparan, is TG which each stanza consists of 31 syllables or more. Tembang Gedhe has considerable metrum. Among the numbers of TG, the well-known and commonly ones used in the community are: basanta, lebda jiwa, kusumawicitra, and manggala gita.

TT is often called sekar tengahan or Tembang dhagelan. It is called so because the creation process is similar to the type of Tembang gedhe and also Tembang cilik. This type of Tembang, in accommodative way, collaborate the two systems of Tembang in one distinctive genre. While the type of metrum is quite a lot, but the famous among others are: balabak, dhudhuk wuluh or megatruh, gambuh, girisa, wirangrong, and jurudemung. While TM or sekar alit etymologically comes from the word "panca" and "papat". The meaning analogically shows the existence of Tembang macapat which consists of 9 pieces. It is also said that macapat is derived from the word "maca" and "papat", which implies a form of Tembang which is read in papat-papat or every row (gatra) consists of 4 words (tembung). However, if it is observed carefully, then the reasons are just a kind of jarwadasa (kirata basa) that is not based on a strong reason, so that the truth is scientifically less-accountable [6], [11].

Tembang macapat consists of 9 types i.e. Tembang (1) pocung, (2) maskumambang, (3) kinanthi, (4) pangkur, (5) asmarandana, (6) mijil, (7) durma, (8) sinom, and (9) dhandhanggula. The nine types of Tembang are not only bound of the rules of creation and the way to sing by the traditional Javanese poetry rules (guru lagu, guru gatra lan guru wilangan), but also has different characteristics in the mission. For example, Tembang which reflects joy, expressions of sadness, expressions of love, anger, and so forth.

\section{b) Content of Tembang}

Philosophically, tembang macapat describes the journey of human life from birth to death. Mijil (come out), means the stage of human life begins from birth; kinanthi (guided), a childhood that is still mentored by parents; sinom (young), youthful passion; asmaradana (fire of love), a period of love or romance, married with a spouse; dhandhanggula (sweet), the stage of people arranging a good, sweet, beautiful, and prosperous life; Maskumambang (filter), the stage when people think of goodness or virtue, but not settled; Durma (understand good and evil), stage of becoming old, time for people to retreat from bad behavior called 'ma lima' (avoiding: 'stealing', 'gambling', drinking 'drunk', 'drug addict' and 'prostitution'; Pangkur (leave worldly pleasure), the next stage is characterized by the attitude of avoiding and putting aside worldly affairs; Gambuh (purpose of life), human stage begins to contemplate life and death; and Pocung (shroud, end of life), self-awareness that the living will surely die. 
Tembang literature which is a traditional art describes its special characteristics. As a cultural portrait, tembang literature has a moral content characteristic characterized by the value of responsibility, conscience, human needs, and order [12].

The content of Tembang literature generally describes flickering of the author's imagination and thoughts about the surrounding environment situation. Such a tendency is in line with Plato's view which states that literary work is a reflection of his society. With the ability, the author (of Tembang) reacts to the result of observations and events around him, and after going through the process of deep thinking and then reflected into masterpiece innovatively and this describes talent and profession.

Based on the identification of literary works of Tembang, the writer's ideas and thoughts are also relatively influenced by the context and condition of the society. Various aspects can be positively lifted as a material for guidance of learner character such as (1) divinity; (2) education; (3) honesty, courage and loyalty; (4) social criticism; and (5) entertainment.

In relation to the divinity aspect, it is normally used by the author to initiate a sacred task or for the benefit of education, every author has different technique of mentioning. Some terms to mention god such as Hyang Widi, Hyang Manon, Hyang Suksma, Hyang Maha Dewa, Gusti, Allah, Hyang Maha Mulya, etc. The following pupuh tembang example may illustrate the religious behavior of the author.

\section{//ASMARADANA//}

Ingsun amiwiti amuji, anyebut namaning Allah, kang murah ing donya mangke, ingkang asih ing akherat, kang pinuji tan pegat, angganjar kawelas ayun, angapura ing dosa.

'I begin (compose) by praising and reciting the name of Allah, the generous in the world and in the Hereafter, who is worshiped every moment, who grants all prayer, and forgives all sins.'

Several matters related to the aspect of education in the art of Tembang usually contains advice, invitations to act or imitate a behavior that is commendable according to the applicable norms. In addition, the intended target is generally clear, whether it is the youth who are in transition period (quest for identity) or certain groups of people who, according to the author's view, need exemplary. The following macapat Tembang will be able to clarify the view.

\section{//POCUNG//}

Siswa iku kudu sing sregep sinau, manut ing parentah, ben dadi bocah kang mursid, setya bekti mbangun miturut wong tuwa.

'Being students should be diligent in learning, following all the rules (in schools), and also be filial to the parents (and teachers), it is a characteristics of good disciples'.

Furthermore, there is also a form of didactic advice related to a form of circumstance or behavior that can help people to reach the prosperous life in the world and hereafter. How should one organize himself in a good social life so that his or her life will be lucked with fortune and peace vertically (with God) or horizontally (with other members of society), the following pupuh Tembang describes it.

\section{//DHANDHANGGULA//}

Yogyanira kang para prajurit, lamun sira bisa anuladha, kadya nguni caritane, andelira sang Prabu, Sasrabahu ing Mahespati, aran patih Suwanda, lelabuhanipun, kang ginelung triprakara, guna kaya purun ingkang den antepi, nuhoni trah utama (Serat Tripama).

'A soldier should be able to imitate Suwanda's patriarchal behavior, the belief of King Sasrabahu of Mahespati, his loyalty and devotion is praiseworthy, he performs his duties wholeheartedly, all he owns are at stake for him, as a testament to the loyalty and soul of a knight.'

The way of criticism, responsiveness or expression of a disagreement (criticism) to a work, state or opinion of others has long been known in Javanese culture. This have varied manifestations. Some are spoken verbally, physically, and some are expressed in writing. Among the three forms of criticism above, the third model is considered the most polite and physically secure. That is because among those who have problem do not meet and also criticism through writing media will possibly be understood with a clearer and wiser mind. In the era where kingdoms are still so dominant in Indonesia, the form of criticism through writing media was displayed in a more subtle and disguised. Moreover, if the criticism is directed to the government (king, for example) then often inserted in literary works, so that even sharp but impressed smooth and beautiful. Only those who understand literature can understand that it is a criticism. As described in the following stanza of serat kalatidha (ronggo warsito):

\section{//SINOM//}

Amenangi jaman edan, ewuh aya ing pambudi, melu edan nora tahan, yen tan melu anglakoni, boya kaduman melik, kaliren wekasanipun, Dilalah kersa Allah, begja-begjane kang lali, luwih begja kang eling lawan waspada.

'Life in a time of madness is troublesome, will follow the taste but not to the heart, but if you do not follow the times you will not gain anything, finally life becomes miserable, however it has become the will of Almighty God, how happy a forgetful (evil) person, then still happier a person who keep in mind (always remember god) and vigilant. '

In addition, an author creates tembang deliberately for the sake of entertaining the heart, declaring an expression of joy that is displayed and sung beautifully. As the characters possessed for each type of Tembang, Tembang pocung is one of the Tembang pocung is one of Tembang macapat that mostly accommodate the aspects of entertainment. The form is various, such as a model "cangkriman" (puzzle), painting of a state, etc. The following pupuh Tembang pocung describes an entertaining character, in a form of a puzzle that must be guessed listeners. 


\section{//POCUNG//}

Bapak pocung rupamu saengga gunung, tan ana kang tresna, saben uwong mesthi sengit, yen kanggonan den luselus tinangisan.

'Bapak pucung your shape is like a mountain, no one cares even everyone feels hatred, but everyone who is occupied will always caress him and even cry for him.'

For people who do not know, they will of course become curious reading the pupuh pucung. That is because finding the flow of thought in the discourse that seems not straight and even the opposite so that it does not make sense. On the one hand, it is said that the pucung is as something that is unpleasant even hated. But on the other hand it is said to be contradictory that whoever occupied by the pucung will always caress (love) and even cry (the impression of happiness). But if it is understood that it is meant as a puzzle to be solved and it turns out that the "bapak pucung" is the guess of "abscess or boil," then what was once an unusual thing becomes acceptable. That is why such an appearance makes the Tembang seems funny and challenging for anyone who reads or hears to try to find the answer.

If the classroom teacher understands enough of the challenging features of the puzzle model and gives a sense of humor it will certainly be able to modify and accommodate the attraction of the Tembang system in teaching. By changing the lyrics of Tembang and filled with other content adjusted to the level of ability and the world of children would be very fun and stimulate student's creativity. If it is successfully done by the teacher, the mission of education and teaching, guidance and cultural preservation, as well as the development of learning strategy of CBSA system with communicative approach and other contextual approach model will produce the expected result.

\section{Teaching Strategy of Tembang Arts}

2 missions of teachers in schools are as teachers and educators. Teachers as educators imply that his duty is as a transmitter of teaching materials. While the task of teachers as educators is not only as a teacher, but the main parameters are focused on the change in attitude and behavior of their students from being ignorant to understanding, being skilled, being respectful. Good Tembang teaching should use titi laras (notation). Good "titi laras" mastery will produce creative students. Not only can they sing the taught Tembang, but also can develop their ability by reading and studying other types of Tembang through the guidance of the existing titi laras. The use of memorizing method (old way) will only produce students who are not creative. That is why such old ways should be reduced and if possible replaced by a titi laras mastery approach. As it is known that the basic of Javanese Tembang use 2 titi laras system (notation) and each is distinguished into 3 pathet. Those titi laras are: (1) laras slendro: pathet nem, sanga, manyura; (2) laras pelog: pathet lima, nem (bem) and pathet barang [6]. Here is the example:

\section{a. Laras Slendro}

$$
\begin{array}{llllllllll}
6 & 1 & 2 & 3 & 5 & 6 & 1 & 2 & 3 &
\end{array} \quad \text { (pt. nem) }
$$

$$
\begin{array}{llllllllll}
5 & 6 & 1 & 2 & 3 & 5 & 6 & 1 & 2 & \text { (pt. sanga) }
\end{array}
$$

$\begin{array}{lllllllllll}5 & 6 & 1 & 2 & 3 & 5 & 6 & 1 & 2 & 3 & \text { (pt. manyura) }\end{array}$

b. Laras Pelog

$$
\begin{array}{llllllllll}
5 & 6 & 1 & 2 & 3 & 5 & 6 & 1 & 2 & \text { (pt. lima) }
\end{array}
$$

$\begin{array}{lllllllllll}6 & 1 & 2 & 3 & 4 & 5 & 6 & 1 & 2 & 3 & \text { (pt. nem/bem) }\end{array}$

\section{$\begin{array}{lllllllllll}5 & 6 & 2 & 3 & 4 & 6 & 6 & 2 & \text { (pt. barang) }\end{array}$}

To understand and master titi laras easier, it is better to use gamelan guidance in the form of saron or gender. The steps taken for good level of mastery is done in 2 stages; (1) memorizing and mastering to the level of inspiring notation or titi laras in succession repeatedly; (2) reading notation randomly. This is to check the level of notation mastery or titi laras to introduce. So does the next until the mastery reaches the level of feasibility and inspiration.

Related to the essence of teaching Tembang, which aims to understand, master, practice and grow respect attitude, then as previously explained there should be an effort to make Tembang meaningful for the students. For that purpose, the language and content of the Tembang should be related to the students' need and ability level. Therefore, the teacher must take a role as initiator, mediator, and transformer of positive cultural values in the art of Tembang by modifying the archaistic poetry into themes or topics and language that is easy for the students to understand. By raising topics around students' experiences and world, it is expected to motivate them to enjoy, learn, explore, and innovatively create in a more functional and contextual world of Tembang literature. Below is an example of the modified model of pupuh Tembang "pucung" and "dhandhanggula":

POCUNG, Lrs. Slendro pt. Manyura

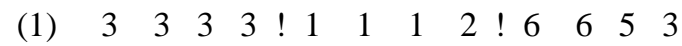

Sis wa $\mathrm{i} k \mathrm{ku}$ sing $\mathrm{ku}$ du sre gep si na $\mathrm{u}$

$\begin{array}{llllllll}1 & 2 & 6 & 3 & ! & 2 & 1 & 0\end{array}$

ma nut ing pa ren tah

$\begin{array}{llllllllll}1 & 2 & 2 & 2 & ! & 3 & 1 & 2 & 6 & 0\end{array}$

ben da di bo cah kang mur sid

$\begin{array}{llllllllllllll}6 & 1 & 2 & 3 & ! & 2 & 2 & 1 & 6 & ! & 1 & 2 & 3 & 2\end{array}$

se tya bek ti mba ngun mi tu rut wong tu wa

(2) Indonesia iku aran negaraku

wis suwe mardika

angrebut saka kumpeni

Landa edan marakna rakyat kangelan.

'Indonesia is the name of my country; it has long been independent by fighting for (liberating) from the colonial Company. The crazy Dutch colonialism (350 years) makes the people miserable'. 


\section{(3) DHANDHANGGULA}

Heh, anakku para mudha-mudhi

kowe kabeh padha angrungokna

saiki maju jamane

aja mung ubyang-ubyung

peplesiran tan maedahi

mung angentekna bandha

pikirane kufur

aluwung padha nindakna

pagawean kreatif lawan produktif

Supaya urip mulya.

'Hi my children the young people, now is the era of competitive progress. Do not waste time and less useful, even just spend the wealth of your parents and behave a bad manner. Develop toward positive and creative activities, so that your life will be happy and glorious. '

\section{CONCLUSION}

Based on the description above, there are several things to infer. At least the following are facts that can be considered in the context of problem-solving efforts in the guidance and teaching of Tembang Macapat that has recently regressed:

Tembang as a literary work contains many positive cultural values and can be used as a source of guidance for building children character. The values that can be developed as teaching material in the framework of character development include the following aspects: religious, education, honesty, courage/loyalty, social criticism, and entertainment.

The success of teaching Tembang is determined by the ability, willingness, and motivation of the teachers. If teachers realize the importance of Tembang as a cultural asset that needs to be preserved and the benefits of the cultural value of Tembang as a medium of education, then there is no reason for teachers to ignore the creativity and innovation in their teaching approach.

Material of Tembang should still be taught to students at schools. It is better to start with a relatively simple Tembang. Then, the students are gradually taught other types of Tembang that fit their level. Tembang lyrics (cakepan) composed by teachers should fit the students level of ability and related to topics around the students world.

Mastery of Tembang should not merely through memorizing activities. In order that students mastery of Tembang can be developed creatively, then the system of mastery of titi laras (notation) is preferred. Teachers should creatively create their own Tembang lyrics that will be taught, and adapted to the conditions of the students ability and context to be more pragmatic and functional.

\section{REFERENCES}

[1] B. Palupi, "Kurikulum Bahasa Jawa KTSP Lengkap". https://www.academia. edu/2010, 2010.

[2] Depdiknas. Propinsi Jawa Tengah. (2013). "Mulok Bahasa Jawa Kurikulum 2013”. class.blogspot.co.id/2014/09/silabus-mulok-bahasa-jawakurikulum 2013.

[3] A. Prihandoko, S. Sarwiji, Sumarlam, "Peningkatan Kemampuan Menemukan Isi dan Pesan Tembang Tembang Macapat dengan Pendekatan Quantum Learning pada Siswa Klas VIIIC SMP Negeri IV Magetan”. Jurnal Pendidikan Bahasa dan Sastra Vol.1, No.1, 2013.

[4] M. Solikhah, "Nilai Etika dan Estetika Tembang Macapat Pupuh Dhandhanggula dalam Serat Nalawasa-Nalasatya dan Pembelajarannya di SMA", Jurnal Program Studi Pendidikan Bahasa dan Sastra Jawa, Universitas Muhammadiyah Purworejo Vol. 05 / No. 05 / Agustus 2014.

[5] A. Moeliono, Kamus Besar Bahasa Indonesia. Jakarta: Depdikbud dan PT. Balai Pustaka, 1990.

[6] A. Efendi, "Mengenal Tembang Macapat". Jurnal Widyatama, No. 2 / Volume 20 / 2011.

[7] S. Santosa, "Nilai-Nilai Pendidikan Moral dalam Tembang Macapat sebagai Penguatan Pendidikan Karakter dalam Kurikulum 2013”. Jurnal AL-BIDAYAH, Pendidikan Dasar Islam, Volume 8, Nomor 1, Juni 2016.

[8] W.J.S. Poerwadarminta,, Baoesastra Djawa. Groningen Batavia: B. Wolters Uitgevers Maatschappij, N.V, 1939.

[9] S. Padmosoekotjo, Ngengrengan Kasusastran Djawa I, II. Kangge Para Siswa Sekolah Guru lan Sekolah Landjutan lijane. Jogjakarta: Penerbit \& Toko Buku Hien Hoo Sing, 1960.

[10] T. Dayati, "Analisis Semiotik Tembang Macapat Pupuh Asmaradana dalam Serat Witaradya 2 Karya Raden Ngabehi Ranggawarsita". Jurnal Program Studi Pendidikan Bahasa dan Sastra Jawa, Universitas Muhammadiyah Purworejo . Vol. 05 / No. 05 / Agustus 2014

[11] S.S. Hutomo, Telaah Kesusastraan Jawa Modern. Jakarta: Pusat Pembinaan dan Pengembangan bahasa, 1975.

[12] S. Wibawa, "Moral Philosofhy in Serat Centhini: Its Contribution for Character Education in Indonesia", Asian Journal Of Social Sciences \& Humanities, Vol. 2 No.04 November 2013. 